\title{
The Policy Development of Social Welfare for Elderly Health Care in the Community: A Case Study of Phitsanulok Municipality, Thailand
}

\author{
Thanach Kanokthet ${ }^{1}$ \\ ${ }^{1}$ Department of Community Health, Faculty of Public Health, Naresuan University, Thailand \\ Correspondence: Thanach Kanokthet. E-mail: thanachk8@gmail.com
}

Received: April 12, 2018

Accepted: May 2, $2018 \quad$ Online Published: June 22, 2018

doi:10.5539/ass.v14n7p1

URL: https://doi.org/10.5539/ass.v14n7p1

\begin{abstract}
This research was aimed at developing a social welfare policy on elderly health care in the community through a case study of Phitsanulok Municipality. The objectives of the study were 1) to develop elements and indicators of social welfare for elderly health care, 2) to develop a model for developing social welfare for elderly health care and 3) to investigate the policy development of social welfare for elderly health care. Mixed Method was utilized using survey component analysis research method, content analysis, component confirmation, deep interview and group discussion. The sample groups in this research are 759 elders and 60 organization managers who are involved in social welfare policy for long term elderly health care.

Results showed 1) social welfare for elderly health care is included in the existing policy in the area and is operational, but it lacks policy contents which are consistent with the needs of the elderly. Additionally, 2) 34 indicators and five elements were identified as components and parameters of social welfare for the elderly in Phitsanulok. Analysis showed the three elements and six indicators are important and two of the six relate to public health. Analysis by Kaiser-Meyer-Olkin Measure of Sampling Adequacy found KMO value equal to 0.912 and structural reliability $\alpha=0.83-0.97$. Lastly, 3) the evaluation results revealed that social welfare policy for elderly health care in Phitsanulok is suitable at a high level.
\end{abstract}

Keywords: policy, social welfare, health, elder

\section{Introduction}

Rational advances in medicine and developments in public health in Thailand have resulted in rapid growth of the number of elderly population. From $10.70 \%$ in 2007 (7.00 million people) to $11.80 \%$ (7.50 million people) in 2012 and a predicted increase to $20.00 \%$ (14.55 million people) in 2025, this is absolutely called "Population Ageing" crisis (Knodel et al., 2010; UNFPA, 2012). Presently, it is already affecting social relationships and cultural and social welfare rights (Barnes et al., 2012).

Improving the quality of life of the elderly in the community using the concept of active ageing or tapping elderly potentials proved to have concrete positive results (Bowling et al., 2013). Nevertheless, this requires concerned organisations to cooperate with partners and stakeholders in all sectors of the community (Black \& Lipscomb, 2017). It is also important that seniors take part in the process of developing the quality of life of the elderly in the community in order to achieve the goals set (Phillips, 2018; Nazroo, 2017; Dong, 2015).

Social welfare services offered by the government for the elderly at present is based on liberal democratic concept of utilising public assistance through a state institution (Institutional model) to provide key social welfare services, a concept of providing information to families and communities used in the service (Lloyd-Sherlock, 2000; Gilleard, 2013). However, this emphasizes more on services for immediate relief more than the development of the elderly to be self-reliant and sustainable over the long term, and thus the quality of service would eventually come short to the requirements and needs of the elderly (Hugo, 2000; Kaambwa et al., 2015). This suggests that using residual model in policy development may not be advantageous and that one size for all approach produces less satisfactory results. It is, therefore, important that elderly people participate in policy setting (Krikorian, Limonero, \& Corey, 2013).

To respond to the needs of the elderly population appropriately, organisations involved in the care of welfare policy should consider the circumstances and context of the community. Elderly population deserves attention and need encouragement for a better quality of life (Rae et al., 2010; Cerin et al., 2016). In doing this, it is 
important to consider the value of honor and dignity of the elderly. In this light, the development of a social welfare policy for the elderly would help improve the life of seniors in Phitsanulok. Nevertheless, since the study location is complex and offers variety of viewpoints in life, social management was not included in the inquiry. The researchers focused on one aspect of the social welfare system for the elderly, and a policy recommendation and public policy related to social welfare for the elderly were later suggested.

\section{Research Objectives}

To develop social welfare policy for the health care of the elderly in Phitsanulok, Thailand, encompassing three main purposes.

1. To develop the elements and indicators in social welfare for the health care of the elderly

2. To develop a model for social welfare development in the health care of the elderly

3. To examine the development of social welfare policies in the health care of the elderly

\section{Research Methodology}

Mixed Methodology was utilized, and it involved three phases.

Phase 1: Survey and analysis of information on social welfare of the elderly health care in the city area as follows.

1) Study theories and previous research, and perform content analysis of documents that relate to the development of social welfare for the health care of the elderly

2) Analyze the process of social welfare of health care for the elderly and the factors that affect the welfare of the elderly's health care by in-depth interviews and focus groups $(n=60)$ who were involved in social welfare policies of the elderly in urban areas.

3) Evaluate the level of social welfare in health care for the elderly using questionnaires collected from participants in the urban areas $(\mathrm{n}=759)$.

\section{Phase 2: Development of a social welfare Model for the health care of the elderly}

1) Development of a social welfare model for the health care of the elderly through a technical meeting and consensus by multipath characteristics (Multi-Attribute Consensus Reaching: MACR)

2) Improvement of the social welfare for the health care of the elderly is confirmed by Factors Analysis.

Phase 3: Evaluation of social welfare development policy in the health care of the elderly by highly qualified professionals and executives through group discussions and interviews from those involved in the social welfare policies of the elderly in urban areas ( $\mathrm{n}=60$ person), followed by content analysis

\section{Results}

In the phase 1 of the study, the following findings were found regarding the basic social welfare for the health care of the elderly in the municipality area.

\section{1}

It was found in the review of literature, both domestic and foreign, that there is consistency of findings relating to social welfare for the health care of the elderly in urban areas; 27 Thai and international research databases were explored. The researchers were able to identify a number of indicators of social welfare for the elderly in urban environment. From this number, 35 indicators were developed and classified into five elements.

1) Public health welfare composed of 11 indicators or 31.43 percent.

2) Social welfare, self-reliance, and culture composed of seven indicators or 20.00 percent.

3) Rights to social welfare and services composed of five indicators or 14.29 percent.

4) Security benefits composed of eight indicators or 22.86 percent.

5) Social welfare network composed of four indicators or 11.43 percent.

\subsection{Evaluation of Social Welfare for the Health Care of the Elderly in Urban Area}

Researchers have set a benchmark for assessing the social welfare of the elderly in the Municipality of Phitsanulok. Normative model was used with the target population to be the standard in order to judge whether there were normality or abnormality in the distribution. The benchmark was divided into three levels using percentile at 25 and 75 to separate the level of responses of the subjects. It was found that there are particular elements that are not normally distributed as shown in Table 1. 
Table 1. Benchmark for assessing the social welfare of the elderly in Phitsanulok, Municipality

\begin{tabular}{|c|c|c|c|c|}
\hline \multirow[b]{2}{*}{ Elements } & \multirow[b]{2}{*}{ Score } & \multicolumn{3}{|c|}{ Benchmark for assessing the social welfare of the elderly } \\
\hline & & $\begin{array}{l}\text { social welfare score } \\
\text { lower than percentile } \\
25\end{array}$ & $\begin{array}{c}\text { social welfare score } \\
\text { between percentile } 25 \\
\text { to } 75\end{array}$ & $\begin{array}{c}\text { social welfare score } \\
\text { higher than } \\
\text { percentile } 75\end{array}$ \\
\hline social welfare in public health & $11-33.0$ & $<16.0$ & $16.0-21.0$ & $>21.0$ \\
\hline social welfare in active aging & $6-18.0$ & $<10.0$ & $10.0-12.0$ & $>12.0$ \\
\hline rights to social welfare and services & $5-15.0$ & $<7.0$ & $7.0-10.0$ & $>10.0$ \\
\hline social welfare in social security & $8-24.0$ & $<13.0$ & $13.0-16.0$ & $>16.0$ \\
\hline $\begin{array}{c}\text { social welfare in social welfare } \\
\text { network }\end{array}$ & $4-12.0$ & $<6.0$ & $6.0-8.0$ & $>8.0$ \\
\hline total & $34-102$ & $<53.00$ & $53.00-65.00$ & $>65.00$ \\
\hline
\end{tabular}

The researchers compared data on the demand of social welfare. It was found that the level of satisfaction with the social welfare was low. Nevertheless, the demand for social welfare was high for those who had higher income level. Although the income level of the elderly among the respondents with an income of their own was moderate, there is still a need to increase income in the Municipality of Phitsanulok.

There are also opinions that income welfare are in much needed of improvement at the moment even from the respondents who have high income levels of their own. The requirement to have a savings fund for the elderly is that the savings fund will be made available to the elderly to help them recover from an emergency, i.e. illness, out of work, or any other circumstance of temporary financial difficulty.

According to the respondents, the social welfare need of the elderly in the part of social security is the recognition of family, neighbors and society. They wanted other people to accept their opinions which is something that usually does not happen in reality because the practice in the cities is to mind one's business. The elderly group expressed need support in health and medical care, and access to hospitals with quality health services.

Although in Phitsanulok Municipality there are many government and private hospitals, the participants believed that their services still lack many things. At present the municipality provide welfare for the elderly and promote activities continuously, but the results of the quantitative research found that the satisfaction level of the respondents at low level, showing they need better welfare. The researchers summarised the points of view of the respondent on elderly welfare in the following table.

Table 2. Comparison of the current welfare and welfare needs of the elderly

\begin{tabular}{ccccccc}
\hline \multirow{2}{*}{ Elements } & \multicolumn{3}{c}{ Current welfare of elderly } & \multicolumn{3}{c}{ Demand welfare } \\
\cline { 2 - 7 } & $(\mathrm{X})$ & (S.D.) & level & $(\mathrm{X})$ & (S.D.) & level \\
\hline 1) Public Health & 1.47 & 0.49 & low & 2.46 & 0.39 & high \\
2) Active Aging & 1.89 & 0.56 & moderate & 2.54 & 0.41 & high \\
3) Rights and Services & 1.68 & 0.41 & moderate & 2.46 & 0.40 & high \\
4) Security & 1.64 & 0.43 & low & 2.42 & 0.50 & high \\
5) Network & 1.56 & 0.31 & low & 2.22 & 0.51 & moderate \\
total & 1.61 & 0.31 & low & 2.38 & 0.29 & high \\
\hline
\end{tabular}

Phase 2: The development of a model in the social welfare for the health care of the elderly

1) The development of a model in the social welfare for the health care of the elderly with the use of Multi-Attribute Consensus Reaching: MACR

The results of median and the inter-quartile range were determined for each indicator on the three-dimensional image based on the consensus of the three groups, including a three-dimensional consistency check. Appropriate dimension and possibilities were determined by a multilateral consensus of experts in the second round. The median (Mdn) and the quartile range (IQR) are shown in the following table. 
Table 3. Median (Mdn) and inter-quartile range (IQR) of social welfare for the health care of the elderly by Multi-Attribute Consensus

\begin{tabular}{|c|c|c|c|c|c|c|c|c|c|}
\hline \multirow{3}{*}{$\begin{array}{l}\text { Component and indicator of social welfare of the } \\
\text { elderly in urban area }\end{array}$} & \multicolumn{9}{|c|}{ Evaluated by Expertise } \\
\hline & \multicolumn{3}{|c|}{ Concordance } & \multicolumn{3}{|c|}{ Suitability } & \multicolumn{3}{|c|}{ Possibility } \\
\hline & Mdn & IQR & Result & Mdn & IQR & Result & Mdn & IQR & Result \\
\hline $\begin{array}{l}\text { Component } 1 \text { social welfare in public health with } \\
\qquad 11 \text { indicators }\end{array}$ & 4.67 & 1.15 & pass & 4.43 & 1.07 & pass & 4.00 & 0.83 & pass \\
\hline $\begin{array}{l}\text { The elderly respondents have at least one health } \\
\text { insurance. }\end{array}$ & 4.56 & 1.18 & pass & 4.20 & 1.44 & pass & 4.19 & 1.03 & pass \\
\hline $\begin{array}{l}\text { They live in a good environment with no harmful } \\
\text { effects on health }\end{array}$ & 3.94 & 0.97 & pass & 3.81 & 1.03 & pass & 3.94 & 0.97 & pass \\
\hline $\begin{array}{c}\text { Their ability in Activities of Daily Living :( ADL) } \\
\text { have been screened. }\end{array}$ & 4.67 & 0.96 & pass & 4.18 & 0.72 & pass & 4.00 & 0.83 & pass \\
\hline $\begin{array}{c}\text { They have been assisted in their daily routine that } \\
\text { requires equipment. (Instrumental Activities of } \\
\text { Daily Living : IADL) }\end{array}$ & 4.75 & 1.04 & pass & 4.43 & 1.07 & pass & 4.42 & 1.17 & pass \\
\hline $\begin{array}{l}\text { They have been assisted in advanced activities of } \\
\text { daily living: (AADL) }\end{array}$ & 4.67 & 1.15 & pass & 4.43 & 1.07 & pass & 4.42 & 1.17 & pass \\
\hline The seniors receive annual health check. & 4.75 & 0.94 & pass & 4.43 & 1.07 & pass & 4.56 & 1.18 & pass \\
\hline $\begin{array}{l}\text { Seniors have used their rights stated in their health } \\
\text { insurance. }\end{array}$ & 4.75 & 0.88 & pass & 4.44 & 1.00 & pass & 4.43 & 1.07 & pass \\
\hline $\begin{array}{l}\text { Seniors receive special service channel which } \\
\text { separate them from general patients in the health } \\
\text { services. }\end{array}$ & 4.56 & 1.00 & pass & 4.25 & 0.88 & pass & 4. 29 & 1.13 & pass \\
\hline $\begin{array}{l}\text { The cause of seniors' illness is not due to the } \\
\text { environment. }\end{array}$ & 3.89 & 0.87 & pass & 3.69 & 1.03 & pass & 3. 69 & 1.11 & pass \\
\hline Seniors receive home visits one time per year. & 3.80 & 1.44 & pass & 3.80 & 1.44 & pass & 3.58 & 1.36 & pass \\
\hline They have been screened for mental illness. & 4.25 & 1.40 & pass & 4.10 & 1.25 & pass & 3.90 & 1.33 & pass \\
\hline Social welfare for active aging with 7 indicators & 4.04 & 0.63 & pass & 4.04 & 0.63 & pass & 3.58 & 1.25 & pass \\
\hline $\begin{array}{l}\text { There is promotion of the integration of the elderly } \\
\text { in the form of groups or clubs. }\end{array}$ & 3.78 & 0.94 & pass & 3. 78 & 0.94 & pass & 3. 69 & 1. 11 & pass \\
\hline Involvement in the community and society. & 4.25 & 1.40 & pass & 4.10 & 1.25 & pass & 3.90 & 1.33 & pass \\
\hline $\begin{array}{l}\text { Provision of activities which are appropriate to the } \\
\text { need of the club or association }\end{array}$ & 4.56 & 1.18 & pass & 4.42 & 1.17 & pass & 4.20 & $1.50^{\mathrm{x}}$ & fail \\
\hline Performance of the role of a wise elder & 4. 75 & 0.94 & pass & 4.56 & 1.07 & pass & 4. 00 & 1. 19 & pass \\
\hline $\begin{array}{c}\text { Creation of a network of social networks with the } \\
\text { elderly outside the area. }\end{array}$ & 4. 42 & 1. 17 & pass & 4.09 & 0.68 & pass & 4. 00 & 0.83 & pass \\
\hline $\begin{array}{l}\text { Appropriate activities for the social status of the } \\
\text { elderly. }\end{array}$ & 4. 56 & 1. 34 & pass & 4.25 & 1.25 & pass & 4. 42 & 1. 17 & pass \\
\hline $\begin{array}{l}\text { Development of the ability to learn of the needs of } \\
\text { the elderly in their life. }\end{array}$ & 4. 75 & 0.94 & pass & 4.56 & 1.07 & pass & 4. 00 & 1. 19 & pass \\
\hline $\begin{array}{c}\text { The } 3 \text { elements of social welfare rights and } \\
\text { services with } 5 \text { indicators }\end{array}$ & 4.42 & 1.17 & pass & 4.00 & 0.83 & pass & 4. 19 & 1. 03 & pass \\
\hline $\begin{array}{l}\text { The respondents receive elderly monetary support } \\
\text { in the amount required by law. }\end{array}$ & 4.75 & 0.94 & pass & 4.67 & 1.15 & pass & 4. 19 & 1. 03 & pass \\
\hline $\begin{array}{l}\text { They have received appropriate occupational } \\
\text { support. }\end{array}$ & 4.75 & 1.04 & pass & 4.67 & 1.15 & pass & 4. 06 & 0.97 & pass \\
\hline $\begin{array}{l}\text { They have received monetary aid or other financial } \\
\text { assistance related to promoting social welfare for } \\
\text { the elderly. }\end{array}$ & 4.75 & 1.04 & pass & 4.40 & 1.31 & pass & 4. 19 & 1. 03 & pass \\
\hline
\end{tabular}


Table 3 (Continued). The median (Mdn) and the quartile range (IQR) of social welfare for health care of the elderly by Multi-Attribute Consensus

\begin{tabular}{|c|c|c|c|c|c|c|c|c|c|}
\hline \multirow{3}{*}{$\begin{array}{l}\text { Components and indicators of social welfare of the } \\
\text { elderly in urban area }\end{array}$} & \multicolumn{9}{|c|}{ Evaluated by Expertise } \\
\hline & \multicolumn{3}{|c|}{ Concordance } & \multicolumn{3}{|c|}{ Suitability } & \multicolumn{3}{|c|}{ Possibility } \\
\hline & Mdn & IQR & result & Mdn & IQR & result & Mdn & IQR & result \\
\hline $\begin{array}{l}\text { Social Welfare Development Center for the Elderly in } \\
\text { four aspects. }\end{array}$ & 4.42 & 1.17 & pass & 4.00 & 0.83 & pass & 4. 09 & 0.68 & pass \\
\hline $\begin{array}{l}\text { Assisting the elderly who were abused, neglected, and } \\
\text { exploited. And the elderly who have special needs. }\end{array}$ & 4.31 & 1.03 & pass & 4.09 & 0.68 & pass & 4. 09 & 0.68 & pass \\
\hline Component 4: Social Security with 8 indicators. & 4. 29 & 1. 13 & pass & 4. 19 & 1.03 & pass & 3.85 & 0.85 & pass \\
\hline $\begin{array}{l}\text { 1) Setting a coordination center for social welfare for } \\
\text { the elderly. }\end{array}$ & 4. 19 & 1.03 & pass & 4. 11 & 0.87 & pass & 3.67 & 1.03 & pass \\
\hline 2) Providing services in religious activities & 4. 13 & 1.40 & pass & 4.00 & 1.17 & pass & 4. 00 & 1. 17 & pass \\
\hline $\begin{array}{l}\text { 3) Arranges events to encourage family members to } \\
\text { acquire knowledge of elder care. }\end{array}$ & 4. 75 & 0.94 & ผ่าน & 4.56 & 1.07 & ผ่าน & 4.00 & 1. 19 & pass \\
\hline $\begin{array}{l}\text { Promotion of the values of coexistence with and } \\
\text { importance of the elderly. }\end{array}$ & 4.14 & 1. 14 & pass & 3.89 & 0.93 & pass & 3. 81 & 1. 20 & pass \\
\hline $\begin{array}{l}\text { Encouragement of the family to let their elders live } \\
\text { with them with quality until the end of their life. }\end{array}$ & 4. 29 & 1. 13 & pass & 4. 19 & 1. 03 & pass & 3.85 & 0.85 & pass \\
\hline $\begin{array}{l}\text { Provision of residential services with the need support } \\
\text { of at least one time per year. }\end{array}$ & 4. 14 & 1. 14 & pass & 4.06 & 0.97 & pass & 3.75 & 1. 33 & pass \\
\hline $\begin{array}{l}\text { Provision of support services to the elderly who have } \\
\text { no families. }\end{array}$ & 4.42 & 1. 17 & pass & 4. 19 & 1.03 & pass & 3.85 & 0.85 & pass \\
\hline $\begin{array}{l}\text { Provision of elderly services and support costs by } \\
\text { local administrative offices. }\end{array}$ & 4. 56 & 1. 34 & pass & 4.29 & 1.13 & pass & 4.06 & 0.97 & pass \\
\hline Element 5: social welfare network with 4 indicators & 4. 42 & 1.17 & pass & 4. 19 & 1.03 & pass & 3.85 & 0.85 & pass \\
\hline $\begin{array}{c}\text { Educational support in both formal and informal } \\
\text { education. (School of Seniors) }\end{array}$ & 4. 29 & 1. 13 & pass & 4. 19 & 1. 03 & pass & 3.85 & 0.85 & pass \\
\hline $\begin{array}{l}\text { Services offered by volunteer caregivers in the local } \\
\text { area. }\end{array}$ & 4. 19 & 1.03 & pass & 4. 11 & 0.87 & pass & 3.67 & 1.03 & pass \\
\hline $\begin{array}{l}\text { Provision of a multi-purpose community center for the } \\
\text { elderly. }\end{array}$ & 4. 56 & 1.07 & pass & 4.29 & 1.13 & pass & 4.06 & 0.97 & pass \\
\hline $\begin{array}{l}\text { Creation of a network for the elderly in order for } \\
\text { seniors to have the opportunity to help each other in } \\
\text { the community and have external network }\end{array}$ & 4. 19 & 1. 03 & pass & 4.11 & 0.87 & pass & 3.92 & 1.48 & pass \\
\hline
\end{tabular}

From Table 3, the researcher considered the result based on the overall consensus of the three groups. Finally 35 indicators were assessed from the 34 indicators, or a sum of 97.14 percent.

2) Improvement of the model of social welfare for the health care of the elderly by confirmatory factor analysis (Factors Analysis)

Statistical Bartlett's test of sphericity on the correlation of indicators were used and findings were used to compare the correlation matrix to the identity matrix. Kaiser-Mayer-Olkin index was also obtained. The researchers wanted to know which variables or correlations were most useful. The analysis of the relationship between variables was an empirical measure of social welfare of the elderly in Phitsanulok. Five elements and 34 indicators were tested in this process. Results are shown in the following figure 

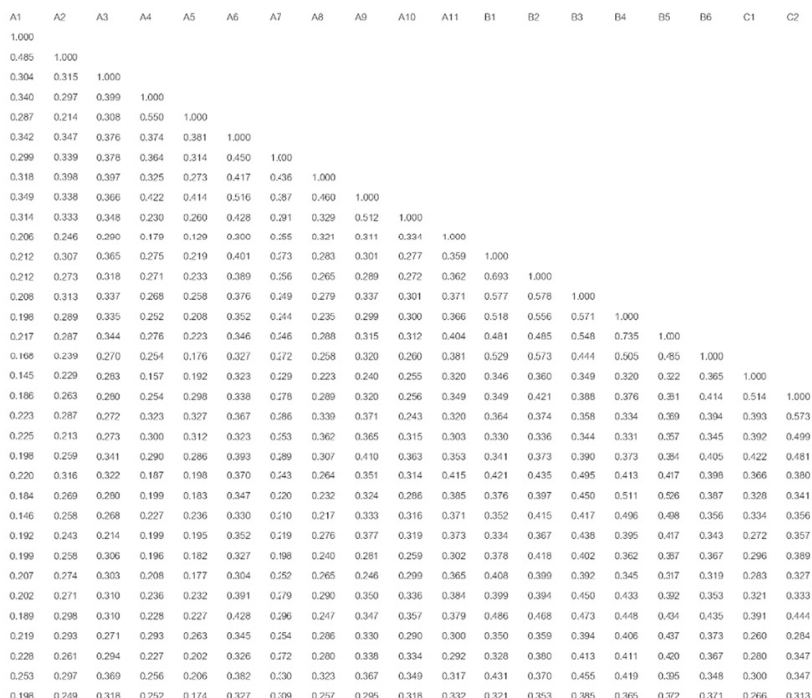

Barlett,s test of Sphericity $=20178.31$ sampling adequacy $=0.912$

$\mathrm{df}=522$

1.000
0.627

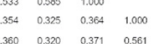

$\begin{array}{llllll}0.337 & 0.330 & 0.391 & 0.457 & 0.603 & 1.020\end{array}$

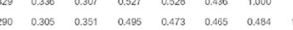

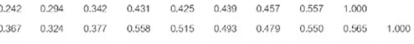

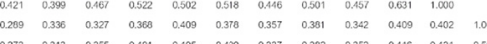

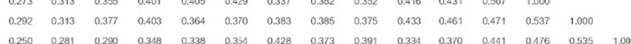
$\mathrm{P}=0.001$ Kaiser- Meyer -Olkin measure of

Figure 1. Correlation Analysis of variables for social welfare of the elderly

The relationships between all the variables of the 561 pairs were not correlated, with statistical significance at 0.05 . Every couple has a relationship by $\mathrm{r}$ value in the range of 0.129 to 0.735 by the relations of elements 1 between. Indicator 5 and indicator 11 were the pair with the lowest relationship value $r=0.129$, while the relationship of elements 2, between indicator 15 (B4) and indicator 16 (B5), was the highest relationship of $r$ value $=0.735$.

The validity of the model.

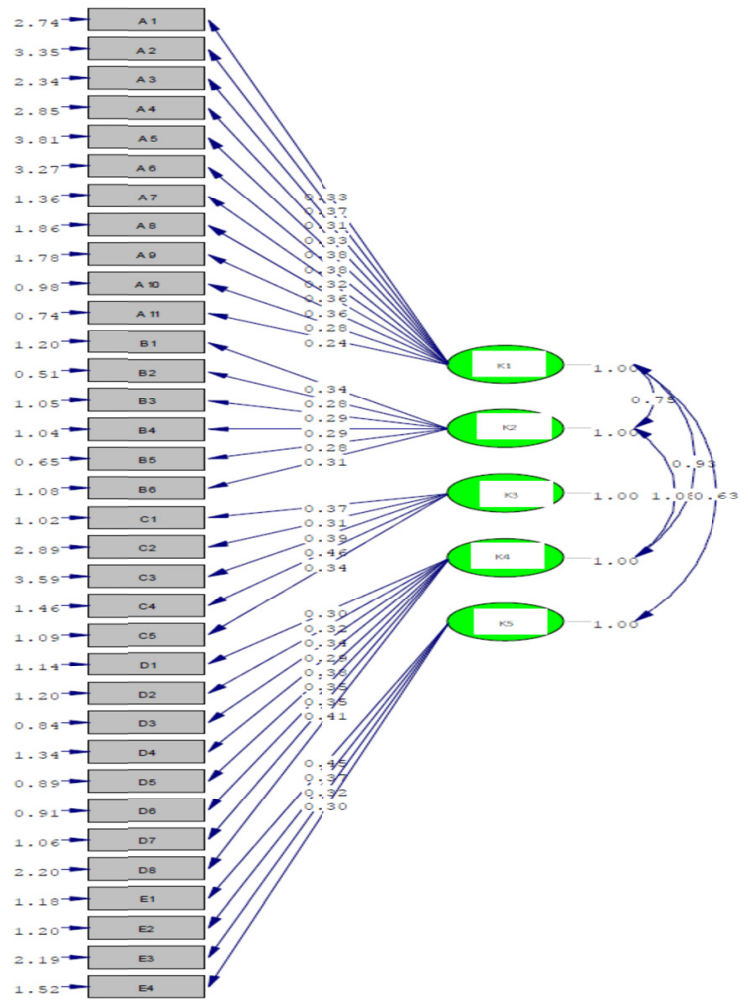

Chi-Square $=505.11, \mathrm{df}=523, \mathrm{P}$-value $=0.70499, \mathrm{RMSEA}=0.000$

Figure 2. Relationship Model of social welfare elements for the elderly

Validity test of the model for social welfare of the elderly in Phitsanulok showed the following results: Chi square was 505.11, degree of freedom was 523, and the probability (p-value) was 0.70499 , significance level at 
0.01 index level. The consonance (Goodness of fit index: GFI) is equal to 0.970 and root mean squared residual or RMR was 0.02 .

Phase 3 Policy evaluation of social welfare in health care of the elderly by professionals

The opinion of professionals showed that "Social welfare policies for the elderly in Phitsanulok" was appropriate at high level (Mean $=4.36, \mathrm{SD}=0.73)$. This means the evaluation result found that policy social welfare for elderly health care in Pitsanulok Municipality was at an appropriate high level.

\section{Discussion}

According to the results, social welfare for elderly health care has been carried out in policy and in performance level, but there is still lacking points in the policy which are consistent with the needs of the elderly. This means the government sector and related organizations adequately supported the activities of the target, but the lack of integration between the various government projects and the absence of process for participation in determining the needs of the elderly resulted into inadequacy of elements in the policy which would answer other important needs of the elderly.

Social welfare for the elderly in Phitsanulok includes 34 indicators and five elements. The analysis showed three elements with 6 indicators are important and 2 of the indicators relate to public health. Additionally, 2 indicators relate to network. The analysis by Kaiser-Meyer-Olkin Measure of Sampling Adequacy found a KMO value equal to 0.912 , which has structural reliability $\alpha=0.83-0.97$. It suggests that social welfare for the elderly in Phitsanulok is valid and reliable and can be used to evaluate social policy in other communities that are contextually appropriate. On the other hand, the educational component is an important part of the requirements set by the elderly in the following areas. This is consistent with the research of Randall, 2013; LaPlante, 2014; Ward \& Gahagan, 2012.

The evaluation result found that policy social welfare for elderly health care in Pitsanulok Municipality has an appropriate high level. Therefore it is appropriate to be used in making recommendations on policy (Shura, Siders, \& Dannefer, 2011; Tine, 2014; Moreira, 2016). Aging in place operates in multiple interacting ways, which need to be taken into account in social welfare policy. The policy of older people have pragmatic implications beyond internal aspects and operate interactively far beyond the housing (Wiles et al., 2012; Wilkinson, 2013; Van Malderen, De Vriendt, \& Mets, 2017; Naldemirci et al., 2016). The themes mentioned by our participants mirror many determinants of successful aging proposed in extant theories. For instance, physical health, mental health and social well-being represent (Jopp et al., 2014; Ward \& Barnes, 2016; McClure et al., 2005).

\section{Recommendations}

1. This study on social welfare needs of the elderly should be presented to other local governments in order to provide data on what they should consider in developing a strategic plan to improve the level of welfare needs of the elderly.

2. The organizations in both the public and private sectors should be involved in promotional activities for the elderly, they should not wait for the unilateral government policy.

3. Supporting activities for seniors should be grouped according to the interest and status of the seniors in order to benefit them and enable them to contribute to society.

\section{Acknowledgement}

The researcher would like to express his gratitude to the National University Commission on Higher Education for funding this research. The researcher also acknowledges the help for mayor of Pitsanulok municipality for the provision of aerial imagery which were very vital in the completion of this research.

\section{References}

Barnes, M., Harrison, E., \& Murray, L. (2012). Ageing activists: who gets involved in older people's forums?. Ageing \& Society, 32(2), 261-280. https://doi.org/10.1017/S0144686X11000328

Black, K., \& Lipscomb, V. B. (2017). The promise of documentary theatre to counter ageism in age-friendly communities. Journal of Aging Studies, 42, 32-37. https://doi.org/10.1016/j.jaging.2017.06.001

Bowling, A., Hankins, M., Windle, G., Bilotta, C., \& Grant, R. (2013). A short measure of quality of life in older age: The performance of the brief Older People's Quality of Life questionnaire (OPQOL-brief). Archives of Gerontology and Geriatrics, 56(1), 181-187. https://doi.org/10.1016/j.archger.2012.08.012

Buffel, T. (2014). Social research and co-production with older people. Developing agefriendly communities, 44, 
52-60. https://doi.org/10.1016/j.jaging.2018.01.012

Cerin, E., Sit, C. H., Zhang, C. J., Barnett, A., Cheung, M. M., Lai, P. C., ... \& Lee, R. S. (2016). Neighbourhood environment, physical activity, quality of life and depressive symptoms in Hong Kong older adults: a protocol for an observational study. BMJ open, 6(1), e010384. https://doi.org/10.1136/bmjopen-2015-010384

Dong, X. Q. (2015). Elder abuse: systematic review and implications for practice. Journal of the American Geriatrics Society, 63(6), 1214-1238. https://doi.org/10.1111/jgs.13454

Gilleard, C. (2013). Renaissance treatises on 'successful ageing'. Ageing \& Society, 33(2), 189-215. https://doi.org/10.1017/S0144686X11001127

Gilleard, C. (2018). Suffering: The darker side of ageing. Journal of Aging Studies, 44, 28-33. https://doi.org/10.1016/j.jaging.2017.12.001

Hugo, G. (2000). 16 Lansia-elderly people in Indonesia at the turn of the century. Ageing in the Asia-Pacific region: Issues, policies and future trends, 2, 299. ISBN 0-203-463080 Master e-book ISBN

Jopp, D. S., Wozniak, D., Damarin, A. K., De Feo, M., Jung, S., \& Jeswani, S. (2014). How could lay perspectives on successful aging complement scientific theory? Findings from a US and a German life-span sample. The Gerontologist, 55(1), 91-106. https://doi.org/10.1093/geront/gnu059

Kaambwa, B., Gill, L., McCaffrey, N., Lancsar, E., Cameron, I. D., Crotty, M., ... Ratcliffe, J. (2015). An empirical comparison of the OPQoL-Brief, EQ-5D-3 L and ASCOT in a community dwelling population of older people. Health and quality of life outcomes, 13(1), 164. https://doi.org/10.1186/s12955-015-0357-7

Knodel, J., Kespichayawattana, J., Saengtienchai, C., \& Wiwatwanich, S. (2010). How left behind are rural parents of migrant children? Evidence from Thailand. Ageing \& Society, 30(5), 811-841.https://doi.org/10.1007/s12126-009-9025-8

Krikorian, A., Limonero, J. T., \& Corey, M. T. (2013). Suffering assessment: a review of available instruments for use in palliative care. Journal of Palliative Medicine, 16(2), 130-142. https://doi.org/10.1089/jpm.2012.0370

LaPlante, M. P. (2014). Key goals and indicators for successful aging of adults with early-onset disability. Disability and health journal, 7(1), S44-S50. https://doi.org/10.1016/j.dhjo.2013.08.005

Lloyd-Sherlock, P. (2000). Old age and poverty in developing countries: new policy challenges. World Development, 28(12), 2157-2168. https://doi.org/10.1016/S0305-750X(00)00077-2

McClure, R. J., Turner, C., Peel, N., Spinks, A., Eakin, E., \& Hughes, K. (2005). Population-based interventions for the prevention of fall-related injuries in older people. The Cochrane Library. https://doi.org/10.1002/14651858.CD004441

Moreira, T. (2016). Science, Technology and the Ageing Society (Vol. 201). Taylor \& Francis. ISBN 978-1-315-74772-9 Master e-book ISBN.

Naldemirci, Ö., Lydahl, D., Britten, N., Elam, M., Moore, L., \& Wolf, A. (2016). Tenacious assumptions of person-centred care? Exploring tensions and variations in practice. Health, 22(1), 54-71. https://doi.org/10.1177/1363459316677627

Nazroo, J. (2017). Class and health inequality in later life: Patterns, mechanisms and implications for policy. International Journal of Environmental Research and Public Health, 14, 1533. https://doi.org/10.3390/ijerph14121533

Phillips, C. R. (2018). Quality of life in the contemporary politics of healthcare:... but what is a life?. Journal of Aging Studies, 44, 9-14. https://doi.org/10.1016/j.jaging.2017.11.001

Rae, M. J., Butler, R. N., Campisi, J., De Grey, A. D., Finch, C. E., Gough, M., ... \& Logan, B. J. (2010). The demographic and biomedical case for late-life interventions in aging. Science Translational Medicine, 2(40), 40cm21-40cm21. https://doi.org/10.1126/scitranslmed.3000822

Randall, W. L. (2013). Aging, irony, and wisdom: On the narrative psychology of later life. Theory \& Psychology, 23(2), 164-183. https://doi.org/10.1177/0959354312470754

Shura, R., Siders, R. A., \& Dannefer, D. (2011). Culture change in long-term care: Participatory action research and the role of the resident. The Gerontologist, 51(2), 212-225. https://doi.org/10.1093/geront/gnq099

UNFPA. (2012). State of World Population 2002: People, Poverty and Possibilities. New York: UNFPA. 
Retrieved from http://www.unfpa.org/swp/swpmain.htm

Van Malderen, L., De Vriendt, P., \& Mets, T. (2017). Active ageing in the nursing home: Could participatory action research provide the answer? Action Research, 15(3), 239-257. https://doi.org/10.1177/1476750316636668

Ward, L., \& Barnes, M. (2016). Transforming practice with older people through an ethic of care. British Journal of Social Work, 46(4), 906-922. https://doi.org/10.1093/bjsw/bcv029

Ward, L., \& Gahagan, B. (2012). Involving older people in research: Empowering engagement? In M. Barnes, \& P. Cotterell (Eds.), Critical Perspectives on User Involvement. Bristol: Policy Press.

Wiles, J. L., Liebing, A., Guberman, N., Reeve, J., \& Allen, R. E. S. (2012). The meaning of "aging in place" to older people. The Gerontologist, 52, 357-366. https://doi.org/10.1093/geront/gnr098

Wilkinson, I. (2013). The problem of suffering as a driving force of rationalization and social change. British Journal of Sociology, 64(1), 123-141. https://doi.org/10.1111/1468-4446.12009

\section{Copyrights}

Copyright for this article is retained by the author(s), with first publication rights granted to the journal.

This is an open-access article distributed under the terms and conditions of the Creative Commons Attribution license (http://creativecommons.org/licenses/by/4.0/). 